\title{
Distal Bile Duct Cancer Clinical Distant Metastasis TNM Finding v7
}

National Cancer Institute

\section{Source}

National Cancer Institute. Distal Bile Duct Cancer Clinical Distant Metastasis TNM Finding v7. NCI Thesaurus. Code C90261.

A clinical finding about one or more characteristics of distal bile duct cancer, following the rules of the TNM AJCC V7 classification system as they pertain to distant metastases. 